\title{
Mutual fund Performance in Nepalese Mutual fund units: An analysis of Monthly Returns
}

\author{
Rajan Bilas Bajracharya \\ PhD Scholar, Mewar University, Rajasthan, India \\ rajan_vj@hotmail.com
}

\begin{abstract}
Mutual funds dwell in a small market in Nepal. Around seven mutual funds listed in the Nepal stock exchange trade (NEPSE). This paper focused on evaluating the performance of five mutual funds of NEPSE on the basis of monthly returns compared to benchmark return. Risk adjusted performance measures suggested by Jenson, Treynor, Sharpe and statistical models are employed. It is found that, most of the mutual funds have performed better according to Jenson and Treynor measures but not up to the benchmark on the basis of Sharpe ratio. However, few mutual funds are well diversified and have reduced its unique risk.
\end{abstract}

KEYWORDS: Mutual fund, Nepal Stock Exchange, Diversification, Net Asset Value.

\section{INTRODUCTION}

Mutual fund is basically a company that pools the money from a group of investors (its shareholders) to buy financial securities, building a less risky portfolio than an individual investor would do (Kolosov \& Soltanmammedov, 2011). In other words, a mutual fund is a company that invests in a diversified portfolio of securities. People who buy shares of a mutual fund are its owners or shareholders. Their investments provide the money for the mutual fund to buy securities such as stocks and bonds. A mutual fund can make money from its securities in two ways: a security can pay dividends or interest to the fund or a security can rise in value. A fund can also lose money and drop in value. The reduced risk of portfolio comes from the benefits of diversification provided by mutual fund managers for investors. Managers charge small amount of fees for their services and for covering the costs associated with trading securities. However, these charges are smaller than those that individual investors would pay if they tried to build on their own similar portfolio of securities. This is because of the economies of scales in transaction costs (Howells \& Bain, 2005, p. 63). Mutual funds today are one of the most studied areas in developed countries due to their efficient and effective role in reducing risk and enhancing return through professional management of funds. These funds boost the incomes of small investors as well as reduce their exposure to unsystematic risks which needs to be taken into consideration for accurate results (Gohar et al., 2011, p. 5583).

To measure the mutual fund performance, some numerical indexes have been devised in literature and these are widely used to in practice. The well-known measure like reward to volatility ratio (Sharpe, 1966) and reward to variability ratio (Treynor, 1965) are indicates the expected return of mutual funds and the risk of the funds. The portfolio evaluation model developed incorporates 
these risk aspects explicitly by utilizing and extending recent theoretical results by Sharpe (1964) and Lintner (1965) on the pricing of capital assets under uncertainty. A measure of portfolio performance is defined as the difference between the actual returns on a portfolio in any particular holding period and the expected returns on that portfolio conditional on the riskless rate, its level of systematic risk, and the actual returns on the market portfolio (Jensen, Michael C 1969). Jensen (1972) and Grinblatt and Titman (1989), (1995) blame security market analysis to overestimate the beta of a market timing fund, and therefore to underestimate its performance. Admati and Ross (1985) and Dybvig and Ross (1985) show that this can occur even if the fund manager chooses a trading strategy which is efficient with respect to her superior information. That research on mutual fund performance based on security market line analysis is unbiased, regardless of whether funds are market timers or not (Alexander and Kreuzberg 2003). Also, Fletcher and Forbes (2004) investigated the performance of mutual funds between January 1982 and December 1996 in the United Kingdom. They applied the stochastic discount factor approach across a wide class of models like CAPM, Campbell's linear factor model, arbitrage pricing theory and Carhart fourfactor model. Fikriyah, Taufiq, and Shamsher (2007) examined 65 mutual funds, including Islamic mutual funds in Malaysia from January 1992 to December 2001. Treynor index, adjusted Sharpe index, Jensen index, and adjusted Jensen index were used to measure the funds' performances. The evidence from Poland (Jędrzej Białkowski, Roger Otten 2011) states that "winning" funds are able to significantly beat the market, based on their significantly positive alphas. Studying an emerging market provides an excellent opportunity to test whether the consensus on the inability of mutual funds in developed and highly efficient markets to beat the market.. Mutual fund is a suitable investment for the common man as it offers an opportunity to invest in a diversified, professionally managed basket of securities at a relatively low cost.

\subsection{Objective of the study}

The main objective of this report is to evaluate the performance of mutual funds and along with to present an extensive analysis the factors which impact the price.

The considerations fundamental the performance evaluation of mutual funds is a matter of concern to the fund managers, investors and researchers. The present paper attempts to answer two questions relating to mutual fund performance.

- How the Mutual fund are earning higher returns than the market returns in term of risk.

- How the mutual funds are offering the advantages of Diversification of securities to their investors.

This paper attempts to answer the questions raised, by firstly describing some basic concepts and later by employing a methodology which was used by Jenson (1968), Treynor (1965) and Sharpe (1966). More than 5 mutual funds are selected for the purpose of this study. The study period is the total period of those mutual funds life period. In this study, the period is selected more than 30 months and some are 12 months or less those are new in market. The data source is monthly Net Asset values (NAVs) published in 'Nepal Stock Exchange'. 


\section{METHOD}

As the topic is related with the performance of mutual funds, I needed different types of information to better evaluate their performance. I have used some information based on price, trade value, turnover of the mutual funds concerned and data related to the market index.

\subsection{Methodology}

2.1.1: The two questions raised in the beginning are answered with the following Methodology.

In order to answer the first question the following measures are adopted. These measures are introduced and tested by Jenson (1968). Treynor (1965) and Sharpe (1966). Basically, these measures are developed on the assumptions of 'The Capital Asset Pricing Model' (CAPM) propounded by Sharpe, Lintner and others. The CAPM specifies that in equilibrium the return and risk are in linear relationship called as Security Market Line (SML).

$r_{p}=r_{f}+\left(r_{m}-r_{f}\right) \beta$

where,

$r_{p}=$ expected return on secutity portfolioP

$r_{f}=$ risk free return

$r_{m}=$ exepectedmarket return

$\beta=$ the measure of systmatic risk of the securityor porfolio

For a well-diversified portfolio, the above relationship can be specified in terms of the total risk ( $r_{p}$ ) of portfolio return, called as Capital Market Line (CML).

where, $\quad r_{p}=r_{f}+\sigma_{p}\left(r_{m}-r_{f}\right) / \sigma_{m}$

$\sigma_{\mathrm{m}}$ is the total risk of Market Index

Though, SML and CML are for the purpose of security return, every security of the portfolio must be plotted on SML and CML. However, well diversified portfolios plot on both the CML and SML, undiversified portfolios plot only on the SML.

The following first two measures are based on the SML, whereas the third one is based on the CML.

\section{a. Jensen Measure}

According to Jensen (1968), equilibrium average return on a portfolio would be a benchmark. Equilibrium average return is the return of the portfolio by the market with respect to systematic risk (volatility) of the portfolio. This is a return the portfolio should earn with the given systematic risk. 
$E A R_{p}=A R_{f}+\left(A R_{m}-A R_{f}\right) \beta_{p}$

Where, $E A R_{p}$ is Equilibrium average Return

Difference between equilibrium average return and average return of the portfolio indicates superior performance of the fund. This is called as alpha $(\alpha)$ Jensenis measure $\left(\alpha_{p}\right)=A R_{p}-E A R_{p}$

If the alpha is positive, the portfolio has performed better and if alpha is negative it has not shown performance up to the bench mark, i.e., the market index.

\section{b. Reward to Volatility Ratio}

This is introduced by Treynor (1965) and similar to the above discussed Jensen measure. Here, additional returns of the portfolio over the risk free return is expressed in relation to portfolio's systematic risk;

$R O V L_{p}=\frac{\text { Total portfolioreturn - Risk freerate }}{\text { Portfoliobeta }} \quad R O V L_{p}=\frac{A R_{p}-A R_{f}}{\beta_{p}}$

where,

$R O V L_{p}$ is reward to volatility of the portfolio.

Here, an additional return of market over risk free return $\left(A R_{p}-A R_{f}\right)$ is the benchmark. Greater value of the portfolio over the market indicates a superior performance of the fund.

The analysis on the basis of above two measures may lead to the same conclusion. This is so because both the measures are based on only systematic risk and exclude unique risk of the portfolio. Hence, it is necessary to evaluate the performance of the fund in terms of its total risk. The following measure is used for the purpose.

\section{c. Reward to Variability}

It was developed by William F. Sharpe (1966). Here, additional portfolio return over risk free return is related with the total risk of the portfolio.

$$
R O V L_{p}=\frac{A R_{p}-A R_{f}}{\sigma_{p}}
$$

The bench mark is additional return of market over risk free return related with market portfolio's total risk. 
$R O V L_{m}=\frac{A R_{m}-A R_{f}}{\sigma_{p}}$

A fund which performed better according to first two measures namely Jensen and Treynor (1965) measures and not according to the third measures indicates the direction in which fund manager has to change the portfolio structure.

2.1.2 The second question of the paper can be answered with the help of three measures which indicate Diversification.

\section{a. Diversification}

One of the important advantages of mutual funds is that a small investor can also enjoy benefits of diversification of portfolio. Further, well diversified portfolio reduces the risk of the portfolio. Diversification can be measured with the help of coefficient of determination $\left(\mathrm{R}^{2}\right)$. This can be obtained by regressing the portfolio's additional return $\left(r_{p}-r_{f}\right)$ against the market additional returns $\left(r_{m}-r_{f}\right)$. A high value indicates greater diversification of fund and vice-versa.

\subsection{Research Design}

The performance of mutual funds has been analyzed using various ratios such as Jenson measure, Sharpe and Treynor- a very much effective ratios calculated in order to obtain an unbiased analysis. Along with that statistical model such as average, correlation and standard deviation have been developed to make the study of mutual funds even more realistic.Diversification pattern of mutual funds and even compared against the standard.

\subsection{Data Analysis}

To analysis the mutual funds data with Jenson measure along with other model, the monthly NAV's and general index data are converted into the annualized data. Different financial model as per the methodology like CAPM model, regression model and so on. Here, the risk free rate is taken as per Treasury bill rate and calculating the return on basis rate. In this report, to show the actual condition of mutual funds, use Sharpe and Treynor index.

In the core of the fund analysis activity lie the double search of judging return and risk. Exposed of a lot of the complexity, this task involves determining a fund's average performance over a period of time. Standard deviation gives a quality rating of an average. A high Standard Deviation may be a measure of volatility, but it does not necessarily mean that such a fund is worse than one with a low standard deviation. 


\section{Results \& Discussion}

\subsection{Performance Evaluation against benchmarks}

Table 1: Return and risk on portfolio

\begin{tabular}{|c|c|c|c|c|c|c|c|c|c|}
\hline $\begin{array}{l}\text { S.N } \\
\text {. }\end{array}$ & $\begin{array}{l}\text { Name of } \\
\text { Mutual } \\
\text { funds }\end{array}$ & $\begin{array}{l}\text { Stock } \\
\text { Symbol }\end{array}$ & Sector & $\begin{array}{l}\text { Averag } \\
\text { e } \\
\text { Monthl } \\
\text { y } \\
\text { Return } \\
\text { on fund } \\
\text { ( ARp) }\end{array}$ & $\begin{array}{l}\text { Averag } \\
\mathrm{e} \\
\text { Monthl } \\
\text { y Risk } \\
\text { Free } \\
\text { Return } \\
\text { on fund } \\
\text { ( ARf) }\end{array}$ & $\begin{array}{l}\text { Averag } \\
\mathrm{e} \\
\text { Monthl } \\
\mathrm{y} \\
\text { Market } \\
\text { Return } \\
\text { (ARm) }\end{array}$ & $\begin{array}{l}\text { Risk } \\
(\sigma p)\end{array}$ & $\begin{array}{l}\text { Risk of } \\
\text { Market } \\
\text { Portfoli } \\
\text { o }(\sigma \mathrm{m})\end{array}$ & $\begin{array}{l}\text { Volatilit } \\
\mathrm{y}(\beta)\end{array}$ \\
\hline 1 & \begin{tabular}{|l|} 
Laxmi \\
Value \\
Fund-1 \\
\end{tabular} & LVF1 & $\begin{array}{l}\text { Mutua } \\
1 \text { Fund }\end{array}$ & $\begin{array}{r}0.0243 \\
3 \\
\end{array}$ & $\begin{array}{r}0.0568 \\
9 \\
\end{array}$ & $\begin{array}{r}0.0075 \\
1 \\
\end{array}$ & $\begin{array}{r}0.0478 \\
6 \\
\end{array}$ & 0.04062 & 0.65939 \\
\hline 2 & $\begin{array}{l}\text { Nabil } \\
\text { Balance } \\
\text { Fund 1 } \\
\end{array}$ & NBF1 & $\begin{array}{l}\text { Mutua } \\
1 \text { Fund }\end{array}$ & $\begin{array}{r}0.0262 \\
6 \\
\end{array}$ & $\begin{array}{r}0.0568 \\
9 \\
\end{array}$ & $\begin{array}{r}0.0203 \\
5 \\
\end{array}$ & $\begin{array}{r}0.0701 \\
7\end{array}$ & 0.07920 & 0.83803 \\
\hline 3 & \begin{tabular}{|l|} 
NIBL \\
Samriddh \\
i Fund 1 \\
\end{tabular} & NIBSF1 & $\begin{array}{l}\text { Mutua } \\
1 \text { Fund }\end{array}$ & $\begin{array}{r}0.0263 \\
9 \\
\end{array}$ & $\begin{array}{r}0.0568 \\
9 \\
\end{array}$ & $\begin{array}{r}0.0067 \\
9 \\
\end{array}$ & $\begin{array}{r}0.0445 \\
7 \\
\end{array}$ & 0.05431 & 0.60866 \\
\hline 4 & $\begin{array}{l}\text { NMB } \\
\text { Sulav } \\
\text { Investme } \\
\text { nt Fund-1 }\end{array}$ & NMBSF1 & $\begin{array}{l}\text { Mutua } \\
1 \text { Fund }\end{array}$ & $\begin{array}{r}0.0405 \\
1 \\
\end{array}$ & $\begin{array}{r}0.0568 \\
9 \\
\end{array}$ & $\begin{array}{r}0.0216 \\
4\end{array}$ & $\begin{array}{r}0.0619 \\
9\end{array}$ & 0.08823 & 0.46460 \\
\hline 5 & $\begin{array}{l}\text { Siddharth } \\
\text { a Equity } \\
\text { Oriented } \\
\text { Scheme } \\
\end{array}$ & SEOS & $\begin{array}{l}\text { Mutua } \\
1 \text { Fund }\end{array}$ & $\begin{array}{r}0.0257 \\
5 \\
\end{array}$ & $\begin{array}{r}0.0568 \\
9 \\
\end{array}$ & $\begin{array}{r}0.0063 \\
6 \\
\end{array}$ & $\begin{array}{r}0.0512 \\
7 \\
\end{array}$ & 0.04405 & 0.61626 \\
\hline 6 & \begin{tabular}{|l} 
Siddharth \\
a \\
Investme \\
nt \\
Growth \\
Scheme-1
\end{tabular} & SIGS1 & $\begin{array}{l}\text { Mutua } \\
1 \text { Fund }\end{array}$ & $\begin{array}{r}0.0271 \\
8 \\
\end{array}$ & $\begin{array}{r}0.0568 \\
9 \\
\end{array}$ & $\begin{array}{r}0.0181 \\
3 \\
\end{array}$ & $\begin{array}{r}0.0716 \\
6 \\
\end{array}$ & 0.07551 & 0.76644 \\
\hline
\end{tabular}

Table 1 presents return and risk of the six mutual funds along with market return and risk. From the table, it is evident that, most of the funds are earning on average 0.0284 percent monthly return, which is moderate to comparing among the mutual funds. But if it is comparing with the market return, it is not goods monthly return of those mutual funds which is lower than the market return. NBF 1 mutual fund has earned an average return of 0.0262

Percent as against the market return 0.0203 percent SIGS 1, SEOS, LVF 1, NMBSF 1 NIBSF 1 have also earned portfolio return lower than market return. Though, with vary limited performance data, they are performed under the average market return. 
However, moderate volatility and risk of mutual funds indicates that investors might have benefited because low risk on portfolio of monthly return against the market return. Further, some mutual fund like NBF 1 and SIGS 1 mutual fund are more risk bearing fund than the market risk and volatility.

\subsection{Diversification}

Table 2:Risk and Diversification

\begin{tabular}{|r|l|l|l|r|r|}
\hline S.N. & $\begin{array}{l}\text { Name of Mutual } \\
\text { funds }\end{array}$ & Symbol & $\begin{array}{l}\text { Risk } \\
(\sigma p)\end{array}$ & Systematic Risk ( $\beta)$ & Diversification (R2) \\
\hline 1 & Laxmi Value Fund-1 & LVF1 & 0.04786 & 0.659397168 & 0.008096368 \\
\hline 2 & Nabil Balance Fund 1 & NBF1 & 0.07017 & 0.838035471 & 0.421726336 \\
\hline 3 & $\begin{array}{l}\text { NIBL Samriddhi } \\
\text { Fund 1 }\end{array}$ & NIBSF1 & 0.04457 & 0.608664898 & 0.007983126 \\
\hline 4 & $\begin{array}{l}\text { NMB Sulav } \\
\text { Investment Fund-1 }\end{array}$ & NMBSF1 & 0.06199 & 0.464606959 & 0.098031912 \\
\hline 5 & $\begin{array}{l}\text { Siddhartha Equity } \\
\text { Oriented Scheme }\end{array}$ & SEOS & 0.05127 & 0.616262513 & 0.088684168 \\
\hline 6 & $\begin{array}{l}\text { Siddhartha } \\
\text { Investment Growth } \\
\text { Scheme-1 }\end{array}$ & SIGS1 & & & 0.443141696 \\
\hline
\end{tabular}

The low $\mathrm{R}^{2}$ value of mutual fund represented the less diversification of the portfolio and the high $\mathrm{R}^{2}$ value indicates the well diversified portfolio. Here, (Table 02) most of the funds indicate the low $\mathrm{R}^{2}$ value like LVF 1(0.00809), NIBSF 1(0.0079), NMBSF 1 (0.098), SEOS (0.0886) mutual fund. As the portfolio is less diversified its unique risk and is high unsystematic risk is low but the total risk is very high.

On the other, NBF 1 mutual fund shows the high $\mathrm{R}^{2}$ value 0.421 and indicates low total risk and systematic risk because of well diversified portfolio. Also SIGS 1 mutual fund represents the well diversified portfolio indicating the high $\mathrm{R}^{2}$ value $(0.4431)$ and low risk.

Ratios and Regression

Table 3: Ratio and Regression

\begin{tabular}{|r|l|l|r|r|r|}
\hline S.N. & $\begin{array}{l}\text { Name of Mutual } \\
\text { funds }\end{array}$ & $\begin{array}{l}\text { Stock } \\
\text { Symbol }\end{array}$ & Sharpe Ratio & Treynor index & Standard Deviation \\
\hline 1 & Laxmi Value Fund-1 & LVF1 & 0.508378198 & -0.049374806 & 0.047862777 \\
\hline 2 & Nabil Balance Fund 1 & NBF1 & 0.374355351 & -0.0365391 & 0.070171129 \\
\hline 3 & $\begin{array}{l}\text { NIBL Samriddhi } \\
\text { Fund 1 }\end{array}$ & NIBSF1 & 0.410515604 & -0.050098522 & 0.04457911 \\
\hline 4 & $\begin{array}{l}\text { NMB Sulav } \\
\text { Investment Fund-1 }\end{array}$ & NMBSF1 & -6.149082719 & -0.035245674 & 0.061994892 \\
\hline 5 & $\begin{array}{l}\text { Siddhartha Equity } \\
\text { Oriented Scheme }\end{array}$ & SEOS & -0.607356452 & -0.050529791 & 0.051270743 \\
\hline
\end{tabular}




\begin{tabular}{|l|l|l|l|l|l|}
\hline $\begin{array}{l}\text { Siddhartha } \\
\text { Investment Growth } \\
\text { Scheme-1 }\end{array}$ & SIGS1 & & & \\
\hline
\end{tabular}

The participants in the market gives abnormal return i.e. it indicated that such funds have not yet saturated in the market.

In addition, Sharpe ratio, and Treynor index is calculated in order to evaluate the performance of the six mutual funds. Sharpe ratio is the returns generated over the risk free rate, per unit of risk. Risk in this is taken to be the funds' standard deviation. Most of the mutual funds SHARPE ratio are positive except two mutual funds. NMBSF 1 and SEOS indicate the negative Sharpe ratio, which means the inferior performance against the market return. LVF 1, NBF 1, NIBSF 1 and SIGS 1 mutual fund indicate the high value. This high value represents the superior performance in the market.

\section{CONCLUSION}

Mutual funds have emerged as the best in terms of variety, flexibility, diversification, liquidity as well as tax benefits. Mutual funds investors can gain access to investment opportunities that would otherwise be unavailable to them due to limited knowledge and resources. Mutual funds have the capability to provide a solution to most investors' requires, however the key is to do proper selection and have a process for monitoring and controlling. In Nepal, the mutual fund industry is at a growing stage and it is incorporating a higher number of new funds every year.

From the above analysis, it can be mentioned that the mutual funds have not performed better than their benchmark indicators. Some of the funds have performed better than the benchmark of its systematic risk but with respect to volatility most of the funds have not performed better. In the sample, funds are not highly diversified unless few mutual funds and because of their high diversification they have reduced total risk of portfolio whereas, other mutual's funds have low diversified portfolio and have more risk.

For expansion the depth of the capital market, it is necessary to float more mutual funds since these are good instruments of mobilizing savings and providing investment opportunities to small savers. Although small in size, mutual funds have contributed toward broadening the base of the country's capital market and co-operated the investors to gain high and relatively secure returns. Despite bright prospects of mobilizing saving and providing investment opportunities to small savers and the ability to meet different risk profiles through providing a wide range of products, one major factor as to why the mutual funds have not emerged as a preferred saving mode is the lack of availability of quality shares and the underdeveloped state of the capital market.

\section{REFERENCES}

Cuthbertson, k. D. (2005, July 14). Mutual Fund Performance: Skill or Luck?

E.F. Fama, K. F. (1993). Common risk factors in the returns on stocks and bonds. Journal of Financial Economics , 3-56. 
Eling, M., \& Faust, R. (2010). The performance of hedge funds and mutual funds in emerging markets. Journal of Banking \& amp Finance, 34 (8), 1993-2009.

Fletcher, D. F. (2004). Performance evaluation of U.K. unit trusts wihtin the stochastic discount factor framework. Journal of Finanicial Reseach,27 , 289-306.

Grinblatt, M. \&. (1992). The persistence of mutual fund performance. Journal of Finance , 197784.

Grinblatt, M., \& Titman, S. (1994). A study of monthly mutual funds return and performance evaluation techniques. Journal of Financial and Quantitative Analysis , 419-444.

Jaydev, M. (1996). Mutual Fund Performance: An analysis of monthly returns,. Finance India, $X$ No. $1,73-84$.

Jedrzej Bialkowski, R. O. (2011). Emerging market mutual fund performance: Evidence for Poland,. The North American Journal of Economics and Finance, 22 (2), 118-130.

Jensen, M. C. (1969). Risk, the Pricing of Capital Assets and the Evaluation of Investment Portfolios. Journal of Business, 42, 167-247.

Jensen, M. (1968). The perfomance of mutual funds in the period 1945-1964. The Journal of Finance, 389-416.

Jones, C. P. (1988). Investments: Analysis and Management. New York: Johneiley \& Sons.

Lehland, H. (1999). Beyound mean variance: Performance measurement in a nonsymmetrical world. Financial Analyst Journal,1 , 27-36.

Lehmann, B., \& Modest, D. (1987). Mutual fund performance evaluation: A comparison of benchmarks and benchmark comparisons. Journal of Finance, 42, 233-265.

Ming-Ming Lai, S.-H. L. (2010). Evaluating mutual fund performance in an emerging Asian economy. The Malaysian experience, Journal of Asian Economics, 21 (4), 378-390.

Roger, O., \& Bams, D. (2000, Sept 21). European Mutual Fund Performance. European Financial Management Journal .

Sharpe, W. F. (1994). Investment . New Delhi: Prentice Hall of India.

Treynor, J. (1965). How to rate management of investment fund. Harvard Business Review , 6375. 